\title{
The member states' contributions to NATO's policy in Afghanistan during Donald Trump presidency
}

\author{
Yu. Boguslavskaya \\ St. Petersburg State University, \\ 7-9, Universitetskaia nab., St. Petersburg, 199034, Russian Federation
}

For citation: Boguslavskaya Yu. The member states' contributions to NATO's policy in Afghanistan during Donald Trump presidency. Vestnik of Saint Petersburg University. International Relations, 2019, vol. 12, issue 1, pp. 40-57. https://doi.org/10.21638/11701/spbu06.2019.103

In a currently highly competitive international environment, US goals of consolidating and strengthening NATO as well as bringing its present mission in Afghanistan to successful termination gain in significance. The success of these processes enhances the reputation of the United States as a powerful international actor. I checked the hypothesis that facing sharp critique from the United States president for free riding in NATO, those members who fail to meet the target of 2 per cent of GDP in their defense expenditure would choose to increase significantly their contributions to the Alliance's efforts in Afghanistan. I did not find enough convincing empirical data to prove it. The contributions of allies rather reflect their power potentials and ambitions they pursue by cooperating in NATO framework. US allies remain able to define the scale of their contribution to collective efforts in NATO framework despite the US pressure. Broadening of the Alliance's purview after the end of the Cold war provided member states with additional alternatives for choosing types of their involvement. My findings generally support the established view on intra-alliance bargaining process in scholarly literature. A wide range of missions in NATO framework and beyond it facilitates coalition formation for the United States with their numerous allies and partners. At the same time, if more major allies further choose to cooperate with Washington outside NATO, it will undermine its effectiveness and global role.

Keywords: NATO, United States, Afghanistan, alliance, politics of prestige, new Europe, old Europe.

As Donald Trump finishes his second year as the President of United States of America, journalists, researches and political analysts around the world widely speculate on the impact his presidency would make on the international system and the US role in the world. Transatlantic relations are also an important issue-area which attracts attention of numerous observers, and which is influenced by Trump's characteristic way of dealing with NATO allies. Though in many respects he tends to continue the policy of previous administration rather than bring about any revolutionary changes, he does that in arrogant and blatant manner by exerting pressure on his counterparts, at least by employing tough political rhetoric.

In the run-up to presidential elections, Donald Trump campaigned on the issue of fair burden sharing in NATO in his attempts to attract voters who felt forgotten and left behind by political elites, who seemed to be too preoccupied with problems of globalized world. After taking office he did not give up completely his populist rhetoric, kept criticiz-

(c) Санкт-Петербургский государственный университет, 2019 
ing US allies for free-riding in the North Atlantic alliance while the United States did the most part, and calling on them to fulfill their commitments. Newly elected president attached much significance to the informal obligations that all NATO members took on by signing the joint declaration after the summit in Wales in 2014 where they expressed the intention to spend no less than 2 per cent of GDP on defense by 2024. Though the allies had a decade to fulfill their promise, Trump mounted pressure on those states who still did not attain the goal, publicly shaming them almost on every occasion.

Never absent from NATO's agenda the issue of burden-sharing became even more salient after the end of the Cold war, when the US allies who enjoyed the peace dividend, decreased their defense budgets. As viewed from Washington's perspective, this move could compromise NATO's international role as effective military alliance. Persistent capabilities gap between the United States and its NATO allies could also become a significant obstacle to success in overseas missions.

Back in 2014, just three member states (United States, Greece, United Kingdom), spent 2 percent or more on defense. According to NATO estimates, in 2018 this number will increase to five (US, Greece, Estonia, United Kingdom, Latvia) with additional three states (Poland, Lithuania, and Romania) approaching this benchmark [1]. Despite their pledges and Trump's pressure, there are still some states like Spain and Hungary who are not likely to meet the target by 2024. A group of countries (Belgium, the Netherlands, Luxembourg, Italy, Portugal, etc.) cannot boast sharp increase in defense expenditure as well [2].

In August 2017, Donald Trump outlined a new strategy of US engagement in Afghanistan that required, inter alia, modest increase ${ }^{1}$ in presence of military personnel from the allied states to train, advice and assist Afghan troops, already deployed in the country as a part of NATO's Resolute Support mission (RSM) that the Alliance had launched in January 2015. For those NATO allies criticized by Trump as 'free riders' for failing to augment sharply defense expenditures, sending additional personnel to Afghanistan was an opportunity to display resolve and solidarity, loyalty and commitment to the Alliance's goals and even to some extent to decrease the diplomatic pressure from Washington.

In fact, those US allies who made large contributions to the mission in Afghanistan (Italy, Turkey, etc.) wanted their efforts to be considered in discussion of burden sharing in NATO, using this fact in inter-alliance bargaining process. Participating in important missions endorsed by Washington could further strengthen their reputations of 'loyal allies' and dispel some criticism for 'free riding' at least for their national audiences. However, James Mattis Trump's Secretary of Defense (2017-2019) clearly indicated that the US preferred no linkage between these issues, reportedly stating "troop contributions to missions did not exempt them from broader spending goals" [2]. It is also worth noticing, that participation in NATO's Resolute Support mission was not the only option for them to display loyalty. In fact, they could choose from a broad set of operation in NATO framework and beyond it, i. e. Baltic air policing operation, patrolling South China Sea, counter-terrorism missions in Syria and Iraq, etc. Even those states who seem committed to stabilization of Afghanistan could opt whether to deploy additional personnel or allocate more money for Trust funds, one of which - Afghan National Army Trust Fund - is operated by the North Atlantic Treaty Organization.

\footnotetext{
${ }^{1}$ In comparison to the 'surge' earlier commanded by the Obama administration.
} 
In this paper, I check the hypothesis that those states who by that time spent on defense less than was pledged in NATO's Wales summit declaration, would use Donald Trump's call to augment personnel in Afghanistan in order to restore their reputations of 'loyal allies'.

I analyze contributions to the RSM by US NATO allies made before December 2018, when Donald Trump announce pullout of the US troops from Syria and his Secretary of Defense James Mattis resigned. Following this announced, there appeared many speculations in US media about the possible withdrawal of a half of the US troops from Afghanistan, though this decision was never publicly announced. This move, if it is done, could become a 'game changer' for those allies who earlier planned to send more personnel to Afghanistan.

I also introduce to analysis of NATO's present day activity the concept of the "policy of prestige" derived from Hans Morgenthau's seminal work "Politics among Nations: Struggle for Power and Peace". I argue that it provides better understanding of the significance of the Alliance's initiatives and activity.

NATO's involvement in Afghanistan presents an interesting case for consideration, since this large-scale out-of-area mission was regarded as a test of the Alliance's ability to act globally and to carry post-Cold war tasks. In a popular move to support the fight against terrorism, NATO assumed command over the International Security Assistance Force (ISAF) established in 2001 under the UN Security Council Resolution 1386, whose goal was "to enable the Afghan Government provide effective security across the country and develop new Afghan security forces" [3]. However, for member states, this mission turned to be almost endless, bringing controversial results and requiring more and more human and financial resources over time [4, p. 109]. By the end of 2014, the ISAF passed its responsibility for stability in the country to Afghanistan security forces. NATO's combat expedition was over. However, starting on January 1, 2015, the Alliance took on a new Resolute Support mission to train, advice and assist the Afghan National Defense and Security Forces (ANDSF), amid the growing pessimism about its outcomes. The success (or failure) of the mission is likely to influence considerably the reputation of NATO as an organization with global outreach and capable for provision of security in remote regions.

\section{Theoretical Framework}

I analyze the decisions taken by NATO as resulting from broad bargaining process inside the Alliance when all states exercise their relative power to influence outcome. John R. Deni succinctly and clearly describes state's bargaining power as a situation "when it has a higher chance of obtaining its preferred outcome" [5, p. 13]. Well aware of asymmetrical relationship in the sphere of security between the United States and its allies, we have to expect that Washington will be able to provide for cooperative behavior of his partners. The likelihood of favorable to the United States outcome will increase with a growing perception of threat to security and interests of all parties.

However, the neorealist literature on alliance politics gives more nuanced picture, suggesting that such factors as state's dependence on alliance, its strategic interest in maintaining it, the clarity of one's commitments as well as the resolve of adversaries can influence bargaining power and its choices to cooperate or to abstain from cooperation [6, 
p. 472-474]. Patricia Weitsman claims that there is also a need to differentiate between wartime and peacetime alliance [7, p.31].

US economist Mancur Olsen introduced the collective action problem to the research on alliances [8], stressing the point that weaker allies whose contributions are rather insignificant have more opportunities (and incentives) to neglect their commitments. Todd Sandler and Keith Hartley proposed two models of collective action in international coalitions: pure public good model and joint product model [9, p. 872, 876].

Wallace J.Thies conducted a detailed empirical research on different issues in relationship between NATO allies. He concluded that member states certainly preferred to provide for security collectively. However, he portrayed them as "burden shifters intent on transferring to their allies responsibility for the collective effort" [10, p.XIV], "simultaneously hoping that their share of the collective burden can be made as small as possible" $[10$, p.XIV].

Some researchers employ the logic of two-level games to explain the outcome of bargaining process, demonstrating that allied support of certain initiatives depends on issue area, where domestic factors tend to be more or less important [11, p.318-319]. In this vein, based on analysis of foreign policy of UK, Canada and Australia in the US war on terror Stefanie von Hlatky concludes that the ability to contribute to Washington's military operations depends on availability of material resources and one's political prowess in forging the domestic coalition in support of the mission [12, p. 19-20]. After working with extensive public opinion polls data, Sarah Kreps claimed that a prolonged NATO's activity in Afghanistan was possible because of the consensus of transatlantic political elites at the time when public in most countries supported immediate withdrawal of troops [13, p. 191].

Recently, the problem of caveats, i.e. allies' imposition of limitations on the use of their troops, attracted attention of scholars [14, p. 67; 15, p.4-5].

Researchers of neoliberal tradition in their works on alliances tend to highlight the influence of political regime of member states on their relationship. One of the most significant examples of this approach is a monograph by Thomas Risse-Kappen "Cooperation among Democracies: The European Influence on U. S. Foreign Policy”. He finds insufficient the explanations of European influence on American foreign policy provided by "traditional alliance theories emphasizing strategic interaction and power-based bargaining". He views the transatlantic alliance as "a community of liberal democracies", whose collective identity shared by the United States as well, has a strong impact on practices the states employ in their interactions. Based on several case studies he concludes that there are three main mechanisms that the European allies use to influence US policies: 1) timely consultation; 2) exposing domestic pressures; 3 ) transnational and transgovernmental coalitions among societal and bureaucratic actors [16, p.4-5].

Thus, a brief review of scholarly literature on inter-alliance bargaining suggests that even in highly asymmetrical relationship there sometimes are several opportunities for relatively weaker states to promote their interests in alliance or at least to refrain from participation in highly unpopular activity.

In this article I analyze the relationship in NATO during the presidency of Donald Trump in the United States with a special consideration given to the Alliance's efforts in Afghanistan. I argue that the concept of "politics of prestige" as described by Hans Morgenthau is useful for deeper understanding of intra-alliance politics of this period. 
Often a neglected issue in the study of international relations, policy of prestige is "as intrinsic an element of the relations between nations as the desire for prestige is of the relations between individuals" [17, p. 86-87]. Prestige for states understood as "reputation for performance and power" [17, p. 95] is even more important than it is for individuals who strive for it out of desire for self-recognition. A reputation of state helps it to achieve its foreign policy goals without resorting to military power or other expensive means of statecraft. Moreover, "it is hoped that the prestige of one's own nation will be great enough to deter the other nations from going to war" [17, p.93]. States pursue policy of prestige in support of a certain policy or for its own sake.

The necessity to maintain NATO's reputation as effective military alliance capable to attain its policy goals and ensure the security of its members explains the insistence of the United States that its allies spend two percent of GDP or more on defense. A benchmark of two percent for defense expenditure for allied states was the result of compromise in NATO. In reality, the fact that state's military spending reaches two percent of GDP does not guarantee its defense capacity. There are great differences in amount of GDP among NATO members. It comes as no surprise that wealthier states with larger GDP have more difficulties in raising defense expenditure to meet the target set in the Wales declaration of 2014 since they have to reallocate larger sums of money. Moreover, GDP indicators are subject to annual fluctuations. Thus, when GDP decreases a state can boast larger percentage spent on defense. The efficiency of spending leaves doubts, too, even though the states, who signed the Wales summit declaration, committed themselves to spend more than $20 \%$ of their defense budgets "on major equipment, including related Research and Development" [18]. According to NATO estimates, 16 out of 29 member states will meet this requirement in 2018, and most of those countries made an impressive progress since 2014 [1].

Meeting the goals of the Wales Summit Declaration symbolizes one's resolve to sacrifice resources for its own security and the Alliance's common cause. Maintaining NATO's reputation as a viable military alliance gains in significance when its relevance and capacity is increasingly questioned inside the Alliance $[19 ; 20 ; 21$, p. 360;22] as well as outside. For example Aleksandr Khramchikhin, the leading Russian military analyst, claims that the European states have passed the point of no return and now, no matter if they reach a benchmark of the Wales declaration or not, they will lack resolve to fight an adversary with commensurate military power [23].

Without considering at length the readiness and overall performance of NATO states troops, in this article I rather work with statistical indicators about each of them, which are available on the North Atlantic Alliance's website. Whether a state meets the Wales Declaration target or not and how impressive is its progress - all these facts are very important during Donald Trump presidency for purely reputational reasons, especially given the significance that the US President himself attaches to these facts in his public speeches and Twits.

As for the role of the conflict in Afghanistan, it gains even more importance for the Alliance's reputation for eradication of terrorism and stabilization, as this Central Asian country increasingly turns into a playground for great powers competing for influence.

Donald Trump employs a technique of 'shaming' the US allies by criticizing in official statements and in his Twits their failure to spend a necessary amount on defense and contribute a fair share to the collective efforts. This political rhetoric technique aims at 
increasing the US bargaining power and mounting more pressure on NATO allies by portraying them as free riders. The publicity of this issue by itself suggests that it is used as a clout on allies. At the same time, in order to decrease this pressure and limit US bargaining power other member states are likely to use defensive rhetoric highlighting their contributions and achievements. By enhancing their role in Afghanistan, at least symbolically, US allies can increase their bargaining power vis-à-vis the United States. Thus, I hypothesize that those NATO states that did not reach the benchmark on defense expenditure will enhance their military role in Afghanistan by increasing the number of troops stationed there.

I view cooperative behavior in NATO framework as a manifestation of willingness to invest resources - human and financial - in maintenance of multilateral organization with a solid base of historically developed institutions with a prominence of the United States. This singles out the North Atlantic Alliance from other forms of bilateral and multilateral cooperation with the US often referred to as 'ad hoc coalitions', 'coalitions of the willing', etc.

\section{Present Challenges in Afghanistan}

By the beginning of Donald Trump's presidency in the United States, NATO was engaged in three main kinds of activity in Afghanistan:

1) Resolute Support Mission (RSM) started in January 2015; it focused "primarily on training, advice and assistance activities at the security-related ministries, in the country's institutions and among the senior ranks of the army and police" [24]. The number of its participants amounted to 39, including the member states and operational partners. According to information on the organization's official website it performs "supporting functions" in such areas as operational planning, budgetary development, force generation process, management and development of personnel; logistical sustainment; and civilian oversight over Afghan national defense and security forces and institutions [24]. As in February 2017, the total number of troops from member states and operational partners participating in RSM was 13,459 [24].

2) NATO ran Afghan National Army (ANA) Trust Fund created in 2007. It was one of the "four funding streams to channel financial support to Afghanistan security forces and institutions" [24]. Initially the mission of the Fund was to support "transportation and installation of donated equipment, to purchase equipment and services for ANA engineering projects, and to support in and out-of-country training" [24], later its scope expanded to include support for literacy, professional training and capacity building, development of good governance, enhancement of participation of women [25]. Recently, NATO and its operational partners decided to extend financial sustainment of the Afghan army through 2024. By July 2016, 31 states - NATO members and the Alliance's partners - collectively contributed 1,555,635,000 dollars [25].

3) In 2010 NATO and Afghanistan signed a Declaration on Enduring Partnership, since then they develop cooperation in such areas as capacity building, professional military education, civil emergency planning and disaster preparedness, public 
diplomacy efforts to provide for better understanding of NATO policy by Afghani public.

Russian former diplomat and lead researcher at MGIMO Centre for East Asian and Shanghai Cooperation Organization Studies Mikhail Konarovsky in his assessment of situation in Afghanistan after 2014 - the year of major withdrawal of US troops - notes with confidence that the country avoided development of the worst-case scenario envisioned by expert community at those times [26, p. 250]. That kind of scenario implied decreasing control of central authorities, "the de facto geographic and political defragmentation of the country, a slide towards chaos and 'war of all against all' and ultimately the Taliban's (forbidden in Russia) total control over the country" [26, p. 250].

However, the situation on the ground was hardly optimistic. The United States were involved in the longest military conflict in their history that had reached a stalemate.

In September, 2017, Bill Roggio and Alexandra Gutowski based on combined analysis of data provided by the Special Inspector General for Afghanistan Reconstruction (SIGAR), the US oversight body, recent media publications and information from Taliban (forbidden in Russia), concluded that at that time the Taliban (forbidden in Russia) controlled 41 and contested 118 districts (about 45 per cent of all country's districts) [27].

In 2017, the UN Assistance Mission in Afghanistan (UNAMA) recorded a nine percent decrease in civilian casualties compared to the year 2016, which became the first year-on-year decrease since 2012. However, there were documented 10453 civilian casualties (3438 deaths and 7015 injured) [28]. The security situation in the country remained volatile. The rise of ISIL-KP (Islamic State of Iraq and the Levant - Khorasan province, forbidden in Russia), whose significant presence in the eastern region of the country is still recorded by UNAMA [29], is the source of regional concern that attracts attention of other powers, like Russia and China to the situation in the country.

Lack of the unity in national government, high level of corruption and state's inability to sustain itself financially without foreign aid further aggravate situation [30, p. 111-113].

In present conditions when the prospects for agreement with the Taliban (forbidden in Russia) on terms favorable to Afghanistan national government remain elusive further decrease in US military presence in the country would have negative impact on regional security. Washington can hardly achieve it without considerable reputational losses. The implication of pulling out troops too early, as in the case of Iraq, can be a tremendous rise in influence of terrorist organizations [31]. Moreover, as the analysis of other issues in US foreign policy confirms [32, p. 121], the increasing rivalry with other powerful international actors, like Russia and China, is likely to require the United States to be even more assertive.

During the electoral campaign, Donald Trump portrayed the mission in Afghanistan as unnecessary, but once in office he had to announce an increase in US military presence. He also called on allies and partners to support Washington's efforts by deploying more troops as a part of Resolute Support Mission. The initial reaction of allies was somewhat mixed. Some states like Spain, Norway and Lithuania confirmed their resolve to assist the United States, while Canada almost immediately publicly refused to return its troops to Afghanistan. Even after the decision was taken in NATO to increase the troop level, most countries did not disclose how much military personnel they were going to deploy. In August 2017, Trump presented his administration's strategy in Afghanistan, whose main 
pillars were conditions-based approach rather than a time-based one, "the integration of all instruments of American power-diplomatic, economic, and military" [33], exerting diplomatic pressure on Pakistan.

A year after outlining the new strategy, the expert assessments of its progress are mixed [34], and US media remains highly critical $[35 ; 36]$. Meanwhile, the percentage of Afghan districts controlled and contested by the Taliban (forbidden in Russia) increased to 60 percent, according to the American Long War Journal [37].

\section{NATO’s Increased Contribution}

I demonstrate recent individual allied contributions to the North Atlantic Alliance's efforts in Afghanistan - as of December 2018 - in the table below. All data is retrieved from the official NATO's website, since it somewhat better depicts the situation on the ground and tends to be more convenient for making comparisons than individual announcements by member states. It can be slightly different to the data provided to other institutions, like Stockholm International Peace Research Institute, but in their bargaining process allied states are more likely to use the alliance's data and indicators. I analyze and discuss below the information from the table.

The analysis of the table above suggests that the United States is more than any other state responsible for increase in the RSM troop number, deploying extra 1534 military personnel. However, their share as a percentage of the whole number of the RSM personnel even decreased to 50 percent, though in February 2017 the Americans made up approximately 52 per cent of the mission's personnel.

By December 2018, according to NATO's official information, 24 out of 29 allies, including the United States, augmented their personnel for the RSM, though their contributions differ in numbers and scale. Most of them, like Poland, presented this decision as resulting from the obvious need to make a fair share in collective efforts, as most other allied states did, and stressed that the RSM was a non-combat mission [44].

Canada and France who don't deploy troops in Afghanistan did not change their initial decisions, largely contributing to international counter-terrorist efforts in Syria and Iraq. The numbers of personnel deployed in Afghanistan by Italy, Turkey and Slovak Republic - the latter's contribution is relatively low - even dropped in comparison to those of the February 2017.

There are some operational partners who currently deploy more troops than individual allies. Georgia who stationed 870 soldiers in Afghanistan and Australia with 300 military personnel currently in the country are the most notable examples. Still, contributions by Armenia (121), Azerbaijan (120) and Mongolia (233) are also worth mentioning [40].

The table above clearly shows that the choice whether to augment troops or not did not depend on whether the state had already met the targets of the Wales summit declaration or not. The progress in this sphere also did not play a significant part in this decision. One can see that states who already can boast their defence expenditures superseding 2 per cent of the GDP augmented their personnel for the RSM. At the same time, all five states who failed to do so by this time spend for defense less than pledged in the Wales summit declaration.

The United Kingdom made a spectacular move. Prior the Alliance's summit in Brussels in July 2018, it pledged to send 440 soldiers in addition to those who were earlier 
NATO in Afghanistan (2018): Individual Contributions by Countries

\begin{tabular}{|c|c|c|c|c|c|c|c|}
\hline & $\begin{array}{l}\text { Resolute } \\
\text { Support } \\
\text { Mission } \\
\text { (February } \\
\text { 2017) }\end{array}$ & $\begin{array}{c}\text { Resolute } \\
\text { Support } \\
\text { Mission } \\
\text { (December } \\
\text { 2018) }\end{array}$ & & $\begin{array}{l}\text { ANA Trust } \\
\text { Fund } 2016\end{array}$ & $\begin{array}{l}\text { ANA Trust } \\
\text { Fund } 2018\end{array}$ & $\begin{array}{c}\text { Defense } \\
\text { Spending as a } \\
\text { Share of GDP } \\
(\%), \\
\text { Estimates for } \\
2018^{\star}\end{array}$ & $\begin{array}{c}\text { Expected } \\
\text { progress } \\
(2014- \\
2018)^{\star}, \% \\
\text { to GDP }\end{array}$ \\
\hline United States & 6,941 & 8,475 & $+1,534$ & & 40.369 .000 & 3,50 & $-0,27$ \\
\hline \multicolumn{8}{|c|}{ Other Framework Nations } \\
\hline Germany & 980 & 1,300 & +320 & 448.159 .000 & 630.000 .000 & 1,24 & $+0,06$ \\
\hline Italy & 1,037 & 895 & -142 & 98.156 .000 & 345.528 .000 & 1,15 & $+0,07$ \\
\hline Turkey & 558 & 501 & -57 & 35.983 .000 & 65.983 .000 & 1,68 & $+0,23$ \\
\hline \multicolumn{8}{|c|}{ Other NATO Europe } \\
\hline Greece & 4 & 10 & +6 & & & 2,27 & $+0,06$ \\
\hline Estonia & 4 & 39 & +35 & 1.098 .000 & 1.498 .000 & 2,14 & $+0,18$ \\
\hline United Kingdom & 500 & 1,100 & +600 & 8.811 .000 & 65.137 .000 & 2,10 & $-0,07$ \\
\hline Latvia & 22 & 40 & +18 & 1.000 .000 & 2.000 .000 & 2,00 & $+0,06$ \\
\hline Poland & 192 & 315 & +123 & & & 1,98 & $+0,13$ \\
\hline Lithuania & 21 & 50 & +29 & 1.052 .000 & 2.052 .000 & 1,96 & $+1,12$ \\
\hline Romania & 588 & 693 & +105 & & 1.471 .000 & 1,93 & $+0,58$ \\
\hline Norway & 42 & 55 & +13 & 77.507 .000 & 102.250 .000 & 1,61 & $+0,10$ \\
\hline Montenegro & 18 & 29 & +11 & 400.000 & 1.600 .000 & 1,58 & $+0,08$ \\
\hline Bulgaria & 86 & 159 & +73 & 714.000 & 1.214 .000 & 1,56 & $+0,24$ \\
\hline Portugal & 10 & 193 & +183 & 2.262 .000 & 4.581 .000 & 1,36 & $+0,05$ \\
\hline Netherlands & 100 & 160 & +60 & 103.879 .000 & 120.8 .000 & 1,35 & $+0,20$ \\
\hline Croatia & 94 & 106 & +12 & & & 1,30 & $-0,10$ \\
\hline Denmark & 97 & 155 & +58 & 24.180 .000 & 30.574 .000 & 1,21 & $+0,06$ \\
\hline Slovak Republic & 40 & 36 & -4 & 1.000 .000 & 2.500 .000 & 1,20 & $+0,21$ \\
\hline Albania & 83 & 136 & +53 & & & 1,19 & $-0,16$ \\
\hline Czech Republic & 216 & 364 & +148 & 1.283 .000 & 2.581 .000 & 1,11 & $+0,16$ \\
\hline Hungary & 90 & 93 & +3 & 800.000 & 1.700 .000 & 1,08 & $+0,22$ \\
\hline Slovenia & 7 & 8 & +1 & 807.000 & 2.557 .000 & 1,01 & $+0,04$ \\
\hline Spain & 8 & 60 & +52 & 5.427 .000 & 5.427 .000 & 0.93 & $+0,01$ \\
\hline Belgium & 62 & 82 & +20 & 30.282 .000 & 54.461 .000 & 0,93 & $-0,05$ \\
\hline Luxembourg & 1 & 2 & +1 & $35,369,000$ & 44.682 .000 & 0,55 & $+0,17$ \\
\hline Iceland & 2 & 3 & +1 & & & & \\
\hline \multicolumn{8}{|c|}{ Nations Not Contributing Personnel for the RSM } \\
\hline Canada & & & & $22,035,000$ & 212.959 .000 & 1,23 & $+0,22$ \\
\hline France & & & & & & 1,81 & $-0,01$ \\
\hline
\end{tabular}

Sources: $[38-43]$. 
deployed there [45] by the end of the year. As in December 2018, according to the information on official NATO's website it deployed additional 600 troops.

While most European states seem to be international actors with regional or at best transregional interests (lying in adjacent regions), post-Brexit referendum UK portrayed itself as 'Global Britain' committed "to the peace and prosperity of the world" [46]. Former UK Foreign Secretary Boris Johnson (2016-2018) and Prime Minister Theresa May promoted the concept of 'Global Britain'. Increased UK contribution to the RSM also demonstrated high significance the United Kingdom attached to its 'special relations' with Washington and its commitment to NATO.

"In committing additional troops to the Train Advise and Assist operation in Afghanistan we have underlined once again that when NATO calls the UK is among the first to answer" [47], declared British Prime Minister Theresa May. At the times, when the UK's relations with the European Union are strained in the course of long and painstaking Brexit, it pledges its allegiance to NATO as important multilateral institution that unites Britain with the United States and most European countries, as May did in the Alliance's headquarters during the July 2018 summit. "NATO is vital today as it ever has been and our commitment to it remains steadfast. The Alliance can rely on the UK to lead by example" [47], May said. While having some budgetary problems, Britain is still likely to spend more than 2 per cent GDP for defense, according to NATO estimates, and as Theresa may claims, it still intends to lead NATO by the power of its example.

UK Ambassador in Afghanistan Sir Nicholas Kay, who was recently appointed as NATO's next Senior Civilian Representative there, in August 2018 had claimed that Trump's strategy for the country "was working" [48]. Still, the Government's decision to augment the personnel for the RSM met some criticism in media. The move was depicted as having to do nothing with British security, the troops were just a "present to Trump" in order to "appease' him, while the economic situation required from the UK more strategic restraint [49].

Germany, Europe's wealthiest economy was one of the largest contributors to the RSM and ANA Trust Fund and one of the four NATO 'framework nations' in Afghanistan, is leading a regional Train, Advise, and Assist Command responsible for coordinating support and capabilities within its respective command region. It became an object of Trump's sharp criticism for failing to meet 2 per cent target. German government chose to send extra 320 troops to Afghanistan, making its contingent one of the largest - $1300-$ up to date and channel more funds to ANA Trust Fund. This choice testifies for Germany's high economic potential as well as the significance it attaches for cooperation in NATO despite publicly displayed tensions with the United States.

Back in 1975, the Federal Republic of Germany's defense expenditure amounted up to 3,13 per cent of GDP. Now, to some commentators, it seems lacking strategy and resolve to boost up its military capabilities [50]. Still, present day Germany wants to assume more responsibility in regional and global scale. At least, Federal Government's Report to the German Bundestag of February 2018 clearly testifies that its approach to engagement in Afghanistan is based on these considerations [51]. It states, that "Germany is committed to the responsibility it took on for the people in Afghanistan, its undertakings to international partners and solidarity among NATO allies" [51, p.6]. Germany adheres itself to multilateral comprehensive civil-military approach without rigid deadlines that would ensure that Afghanistan's sufficient stability and that it would not "pose a threat to Germany, 
its allies and the region" [51, p.6]. German government links its prolonged engagement with Afghanistan with the task to reduce the causes for migration.

Germany's stated goals of joint engagement are broad. They include reducing the violent conflict, creating legitimate and stable state in Afghanistan, ensuring economic and social development, fostering an Afghan-owned peace process that is supported by other countries in the region [51, p.7]. Germany calls for "strategic patience" in order to give Afghan government time to become effective. Critics claim that Germany's mission in the country remains vague and its desired outcomes cannot be achieved in foreseeable future [52]. German Green party also shares the view that the operation in Afghanistan can be endless.

On the military side, the aforementioned report of the German government claimed that as a framework nation Germany should be "flexible, so that it could fill capability shortfalls that might arise among its multinational partners in the North" [51, p. 12] and that it "had no military assets at its disposal to react to unexpected situations that might arise" [51, p. 12]. An expected decision to send more troops to Afghanistan came amid the criticism of the German military for being able to carry out only about a half of its joint operations with the Afghan army in winter 2018 [53].

As in summer 2018, Italy had about 5000 troops on foreign deployment worldwide, much more than some other European NATO states like Germany (3 800) and Spain (1700) [54]. Extensive participation in military operations is viewed by some as a means to maintain and even increase Italy's role [54] in international arena and among US European allies in particular. The former cabinet of Paolo Gentilone did not object to the American requirement to increase defense spending but played for time without making significant decisions in this sphere. In its political rhetoric it referred to multiple military operations where Italy participates, including that in Afghanistan, that should be also counted as the country's contribution to collective efforts [55].

During the run-up to the parliamentary elections in Italy in 2018, the leader of the populist Five-Star Movement (M5S) Luigi Di Maio stated that Italy should pull out of the NATO's Resolute Support Mission in Afghanistan, as it exposed Italian soldiers "to pointless risks" [56]. After winning relative success in elections and making a ruling coalition with Lega Nord in March 2018, M5S took a more traditional approach to its NATO policy. Though the possibility of Italy's reduction of its RSM personnel still exists, it launched an air policing mission in Montenegro alongside with Greece.

Even more important than populist rhetoric of M5S for Italy is its strategic considerations. It finds itself a 'frontline state' on NATO's Southern Flank lying on the crossroads of major migrant routes and exposed to the threats of political instability in Africa and the Middle East. Its commitment to NATO's engagement in Afghanistan can be further compromised by its interests and immediate threats in the neighboring regions. Currently Italy also prepares for a new mission in Niger to counter human trafficking.

The other RSM framework nation - Turkey - not only faces immediate threats of civil war in neighboring Syria and rising influence of Kurdish community, it also wants to play a more assertive role as NATO's largest nation with predominantly Muslim population. These two conflicting incentives are likely to influence Ankara's policy in Afghanistan.

As previously mentioned, the RSM is NATO's non-combat mission, and the number of international troops currently stationed in Afghanistan is considerably lower than before the end of 2014. The high influence of the Taliban (forbidden in Russia) in the coun- 
try as well as the activity of other terrorist groups, including the ISIL-KP (forbidden in Russia), and illicit trade in drugs remain sources of concern. However, for many member states, the conflict in Afghanistan is a remote mostly "American war", while now they face crucial challenges of terrorism and uncontrolled migration emanating from the adjacent regions of Africa and Middle East. Still, the perceptions about the scales of those threats differ considerably depending on what region of Europe is concerned. Earlier experiences with unpopular combat mission in Afghanistan, causing casualties and growing expenses also influence European attitudes.

A decision to augment, at least symbolically, their military presence in Afghanistan is a face-saving gesture in a hope to increase to some extent its bargaining power in dealing with the United States, while facing sharp criticism of Donald Trump.

Though Spain's contribution of troops to the RSM is low in comparison to those of other member states and operational partners, former Prime Minister Mariano Rajoy (2011-2018) of People's Party was one of the first foreign leaders who responded Trump's call to increase military presence [57]. The government of Rajoy anchored its hopes on closer relations with Washington and even aspired a role of intermediary between the United States and the EU after Brexit. Even more important, Rajoy wanted to contrast himself to the former Socialist Workers' Party government of José Luis Rodríguez Zapatero (2004-2011) who pulled Spanish troops from Iraq and reportedly missed many opportunities in relationship with Washington. Thus, there were hopes to use cooperative behavior in NATO as a clout in domestic politics as well.

Contrary to my hypothesis, success or failure to meet NATO guidelines on defense expenditure does not seem to be a decisive factor defining the significant increase in contributions to the Alliance's efforts in Afghanistan. There are cases when allies with low indicators just symbolically increased their presence (Hungary, Slovenia) or even decreased it (Slovak Republic, Italy). At the same time, states who met the goal of 2 per cent or almost met it, noticeably built up their presence (UK, Poland and Romania).

In some instances, the hypothesis finds some empirical support. The contribution of Greece, whose military expenditures amount to 2, 27 per cent of its GDP, to the RSM is relatively low according to the information on NATO official website. However, in June 2018, the Hellenic Air Force sent a team of technical advisers to Afghanistan to display the commitment of Athens to allied efforts [58].

Russian prominent diplomat and researcher Yevgeniy M. Primakov claimed that one of the reasons of NATO enlargement was "strengthening of intra-bloc discipline" [59] by inclusion new members, more loyal to Washington than the old ones. Later research on countries' of the 'new Europe' participation in military operations of North Atlantic Alliance deriving empirics from NATO's intervention to Libya in 2011, demonstrated that Central and Eastern European nations were more eager to participate in missions in which Washington was particularly interested and played prominent role [60, p. 360-362].

The case of recent NATO military buildup in Afghanistan that I consider in this article suggests that states of 'new Europe' tend to demonstrate loyalty to Washington, though contributions of some of them to RSM and ANA Trust Fund are very small in comparison to those of other allies, as in case of Hungary, Slovenia, Montenegro, Slovak Republic. However, the cases of Romania, Poland and Baltic states are more complicated. Those states increased their contributions to the RSM, while they could probably avoid it referring to the threat of Russia. 
As for the states of the 'old Europe', their contribution in Afghanistan seems to be more significant. All 'framework nations' providing most troops for the RSM, except for the United States, belong to 'old Europe' (Germany, Italy, Turkey). Europe's larger and wealthier economies more often than not belong to this group as well. They channel significantly larger funds to ANA Trust Fund. However, when it comes to troop numbers, one should place Georgia and Romania along the aforementioned 'framework nations' to the list of the largest contributors. And, of, course, allies may provide some auxiliary support that I do not analyze here, like, for example, Slovak Republic, who organized the training of Afghani helicopter pilots in its facilities in Košice [61].

The cases of states who do not participate in collective efforts in Afghanistan or recently decreased their contributions are also worth consideration. Canada, who has "no plans" to double its defence budget, according to her Prime Minister Justin Trudeau [62], refrained from returning its troops to Afghanistan, which they left in March 2014. It is Canadian prime minister who claims that meeting a 2 per cent target is a wrong indicator of ally's commitment and that one has to assess state's participation in combat missions. Though absent from Afghanistan, Canada focuses on other important NATO operations. Recently it increased military deployment in Latvia up to 540 troops and extended its mission through another four years. It will also run NATO's training mission in Iraq.

France positions itself in the North Atlantic Alliance as 'steadfast but independent ally' [63], strongly committed to the fight against terrorism. After signing a friendship and cooperation treaty with Afghanistan on 27 January 2012, France stresses its predominantly civilian role in the stabilization of the country [64]. French President Emmanuel Macron endorsed Trump's new strategy in Afghanistan, but Paris still refrains from participation in the RSM. France acts outside the Alliance framework and focuses on fighting terrorism in the Middle East and bringing stability to Africa.

An in-depth research on the French experience with Afghanistan demonstrates that "the French government never really tried to develop a coherent and consistent strategic narrative to convince the public about the necessity to intervene in Afghanistan. The purpose of the French deployment and the prospect of success were never directly exposed" [65; p. 124]. Ronald Hatto describes the reaction of the French public to the Afghan war as benign neglect, absent profound domestic discussion, until Nicolas Sarkozy's government decided to augment the French presence there in 2008 [65, p. 125]. However, then the valuable time to explain to the public the goals of the deployment was lost, and powerful critical narratives appeared in mass media.

The same criticism widely remained in French media accounts of the events in Afghanistan and efforts by the United States, its allies and partners, when Donald Trump unveiled his strategy. They mentioned that the reason behind the US president revised his approach to Afghanistan was ousting from Trump's administration his key strategist and ideologist Stephen K. Bannon, who advocated lessening of the US global role, and also growing influence of the 'generals' in the White House - namely Secretary of Defense James Mattis, National Security Adviser H. R. McMaster, White House Chief of Staff John Kelly [66]. The same editorial in "Le monde" described the war in Afghanistan as "a war of attrition, distant, difficult and ungrateful, which has already cost the lives of more than 2,000 Americans and thousands of Afghans" [66]. The same criticism and pessimistic accounts of the situation in Afghanistan were quite common for Canadian media coverage. One piece of text is even worth citation, since it went so far as to saying that the Afghans 
questioned real intentions of the West. "Many Afghans, including Karzai, are convinced that the United States and NATO have the military ability to defeat the Taliban (forbidden in Russia). But with the war raging 16 years after the Taliban were ousted, they accuse the West of seemingly wanting chaos over peace" [67].

When Donald Trump unveiled his strategy for Afghanistan there were many doubts in the United States as well whether it would work. Sending more troops there without clear deadlines intended to exert additional pressure on the Taliban (forbidden in Russia) and Pakistan who supports it. However, the discussion on whether the US should focus more on counter-terrorism measures or negotiate peaceful settlement with the Taliban without sending extra troops continued [68]. This perceived lack of clear strategy how to end up the conflict coupled with Trump's tardiness in presenting his admiration's policy further complicated the mobilization of public support for collective efforts in Afghanistan in all NATO states.

\section{Conclusions}

In the context of increased competition in international arena, the goals of consolidating and strengthening NATO as well as bringing its current mission in Afghanistan to successful termination gains even more significance in practical terms. It is also a means to sustain the solid reputation of the United States as a powerful international actor.

I checked the hypothesis that facing sharp criticism from the United States president for free riding in NATO, those members who fail to meet the target of 2 per cent of GDP in their defense expenditure would choose to increase significantly their contributions to the Alliance's efforts in Afghanistan. I did not find enough convincing empirical data to prove this hypothesis. Official information on increased contributions of member states provided a somewhat mixed picture. Those contributions rather reflect the power potentials of member states and ambitions they pursue by cooperating in NATO framework.

The pressure of the United States on its allies remains high in the considered period of Trump presidency. Generally, US allies seem to retain some interest in preserving the Alliance. At the same time, they remain able to define the scale of their contribution to collective efforts in NATO framework. The considerable broadening of the Alliance's purview after the end of the Cold war provides member states with additional alternatives for choosing the types of their involvement. Given the possibility for its numerous allies to choose in what missions they want to participate side by side with Washington - in NATO framework as well as beyond it - the latter finds it relatively easy to form coalitions and maintain consensus among its partners. Still, progressing inclination of NATO states to opt for missions beyond the Alliance's framework can undermine its effectiveness and global role.

\section{References}

1. Defense Expenditures of NATO Countries (2011-2018). Press Release. July 10, 2018. Available at: https://www.nato.int/nato_static_fl2014/assets/pdf/pdf_2018_07/20180709_180710-pr2018-91-en.pdf (accessed: 02.08.2018).

2. Emmott R., Ali I. US Tells NATO Allies Spending Plans Still Falling Short. Available at: https:// www.reuters.com/article/us-usa-trump-nato/u-s-tells-nato-allies-spending-plans-still-falling-shortidUSKCN1FY013 (accessed: 01.09.2018). 
3. ISAF's Mission in Afghanistan (2001-2014) (Archived). Available at: https://www.nato.int/cps/ us/natohq/topics_69366.htm (accessed: 02.08.2018).

4. Vlasov N. A. Uroki Gindukusha: Missiya Bundesvera v Afganistane I politika bezopasnosti FRG [Lessons of Hindu Kush: the Mission of the Bundeswehr in Afghanistan and its Impact on German Security Policy]. Vestnik SPbGU. Ser. 6. Political Science. International Relations, 2016, is. 3, pp. 108-121. (In Russian)

5. Deni J.R. Alliance Management and Maintenance: Restructuring NATO for the $21^{\text {st }}$ Century. London, Routledge, 2007. 286 p.

6. Snyder G.H. The Security Dilemma in Alliance Politics. World Politics, 1984, vol.36, no.4, pp. 461-495.

7. Weitsman P.A. Dangerous Alliances: Proponents of Peace, Weapons of War. Stanford, Stanford University Press, 2004. 244 p.

8. Olson M., Zeckhauser R. An Economic Theory of Alliances. Memorandum RM-4297-ISA. October 1966. Available at: https://www.rand.org/content/dam/rand/pubs/research_memoranda/2007/ RM4297.pdf (accessed: 02.09.2018).

9. Sandler S., Hartley K. Economics of Alliances: The Lessons for Collective Action. Journal of Economic Literature, 2001, vol. 39, is. 3, pp. 869-896.

10. Thies W. J. Friendly Rivals: Bargaining and Burden Shifting in NATO. London, Taylor \& Francis, 2015. $368 \mathrm{p}$.

11. Kupchan Ch. NATO and the Persian Gulf: Examining Intra-Alliance Behavior. International Organization, 1988, vol.42, is. 2, pp.317-346.

12. Von Hlatky S. American Allies in Times of War: The Great Asymmetry. New York, Oxford University Press, 2013. 181 p.

13. Kreps S. Elite Consensus as a Determinant of Alliance Cohesion: Why Public Opinion Hardly Matters for NATO-Led Operations in Afghanistan. Foreign Policy Analysis, 2010, vol. 6, is. 3, pp. 191-215.

14. Saideman S.M., Auerswald D.P. Comparing Caveats: Understanding the Sources of National Restrictions upon NATO's Mission in Afghanistan. International Studies Quarterly, 2012, no. 56, pp. 67-84.

15. Fermann G. Coping with Caveats in Coalition Warfare: An Empirical Research Program. London, Taylor \& Francis, 2019. 281 p.

16. Risse-Kappen T. Cooperation among Democracies: The European Influence on U. S. Foreign Policy. Princeton, Princeton University Press, 1997. 250 p.

17. Morgenthau H.J., Thompson K.W. Politics among Nations: the Struggle for Power and Peace. $6^{\text {th }}$ edition. New York, Alfred E. Knopf, 1985. 380 p.

18. Wales Summit Declaration. Issued by the Heads of State and Government participating in the meeting of North Atlantic Council in Wales. 05 Sep. 2014. Available at: https:/www.nato.int/cps/ic/natohq/ official_texts_112964.htm (accessed: 03.09.2018).

19. Whiton Ch. NATO Is Obsolete. National Interest. July 6, 2018. Available at: https://nationalinterest. org/feature/nato-obsolete-25167 (accessed: 02.09.2018).

20. The Growing Irrelevance of NATO. Available at: https://worldview.stratfor.com/article/growingirrelevance-nato (accessed: 02.09.2018).

21. Williams M. J. Enduring, but irrelevant? Britain, NATO and the future of the Atlantic alliance. International Politics, 2013, vol.50, is. 3, pp.360-386.

22. Rupp R. Israel in NATO? The National Interest. November, 10, 2006. Available at: https:// nationalinterest.org/article/israel-in-nato-1297 (accessed: 02.09.2018).

23. Khramchikhin A. A. Budet li Rossiia okkupirovat' Evropu? Rukovodstvo NATO okazalos' v plenu sobstvennykh strategicheskikh illuzii [Will Russia occupy Europe? NATO Leadership Was Taken Prisoner of their Own Strategic Illusions]. Available at: http://nvo.ng.ru/realty/2018-09-13/1_1013_occupation.html (accessed: 02.09.2018). (In Russian)

24. NATO and Afghanistan. Available at: https://www.nato.int/cps/en/natohq/topics_8189.htm (accessed: 08.09.2018).

25. Afghanistan National Army (ANA) Trust Fund. July 2016. Available at: https://www.nato.int/ nato_static_fl2014/assets/pdf/pdf_2016_07/20160701_1607-factsheet-ana-tf.pdf (accessed: 02.09.2018).

26. Konarovsky M. Afghanistan after 2014. International Organizations Research Journal, 2017, vol. 12, no. 3, pp. 242-253. 
27. Roggio B., Gutowski A. LWJ Map Assessment: Taliban Controls or Contests $45 \%$ of Afghan Districts. Available at: https://www.longwarjournal.org/archives/2017/09/lwj-map-assessment-talibancontrols-or-contests-45-of-afghan-districts.php (accessed: 10.09.2018).

28. Afghanistan. Protection of Civilians in Armed Conflict. Annual Report 2017. Available at: https:// unama.unmissions.org/sites/default/files/afghanistan_protection_of_civilians_annual_report_2017_ final_6_march.pdf (accessed: 02.09.2018).

29. The Situation in Afghanistan and its Implications for International Peace and Security. Report of the Secretary-General. 10 September 2018. Available at: https:/unama.unmissions.org/sites/default/files/ sg_report_on_afghanistan_12_sept.pdf (accessed: 15.09.2018).

30. Fair C. Ch. Afghanistan in 2017. Another Year of Running in Place. Asian Survey, 2018, vol. 58, no. 1, pp. 110-119.

31. Batyuk V. Novaia strategiia SShA v Afganistane [New US Strategy in Afghanistan]. Available at: http://russiancouncil.ru/analytics-and-comments/analytics/novaya-strategiya-ssha-v-afganistane/ (accessed: 15.09.2018). (In Russian)

32. Tsvetkova N.A. Publichnaia diplomatiia SSHA: ot 'miagkoi sily' $\mathrm{k}$ 'dialogovoi propagande' [New Forms and Elements of US Public Diplomacy: From Soft Power to Dialogue-Based Propaganda]. Mezhdunarodnye protsessy, 2015, vol. 13, no. 3 (42), pp. 121-133. (In Russian)

33. Trump D. J. Remarks of President Trump on the Strategy in Afghanistan and South Asia. August 21, 2017. Available at: https://www.whitehouse.gov/briefings-statements/remarks-president-trump-strategyafghanistan-south-asia/ (accessed: 15.09.2018).

34. Taurangbam M., Palrecha N. Trump's Strategy in Afghanistan: The Beginning of an Indefinite End. Available at: https://thediplomat.com/2018/06/trumps-strategy-in-afghanistan-the-beginning-of-anindefinite-end/ (accessed: 15.09.2018).

35. Seligman L. One Year On, Little to Show for Trump's Afghanistan Strategy. Available at: https:// foreignpolicy.com/2018/08/23/one-year-on-little-to-show-for-trumps-afghanistan-strategy/ (accessed: 15.09.2018).

36. Walsh N.P. Trump's Strategy Is Failing and the Taliban Is Winning. Available at: https://edition. cnn.com/2018/08/16/asia/afghan-analysis-npw-intl/index.html (accessed: 15.09.2018).

37. Roggio B. Taliban Operations Span the Entire Country, Afghan Interior Ministry Confirms. Available at: https://www.longwarjournal.org/archives/2018/06/taliban-operations-span-the-entirecountry-afghan-interior-ministry-confirms.php (accessed: 15.09.2018).

38. Trump Got from NATO Everything Obama Ever Asked For. July 12, 2018. Available at: https:// www.nytimes.com/2018/07/12/opinion/editorials/trump-nato-obama.html (accessed: 15.09.2018).

39. Resolute Support Mission (RSM): Key Facts and Figures. December 2019. Available at: https:// www.nato.int/nato_static_fl2014/assets/pdf/pdf_2018_12/20181203_2018-12-RSM-Placemat.pdf (accessed: 24.01.2019).

40. Resolute Support Mission (RSM): Key Facts and Figures. February 2017. Available at: https://www. nato.int/nato_static_fl2014/assets/pdf/pdf_2017_02/20170209_2017-02-RSM-Placemat.pdf (accessed: 24.01.2019).

41. Afghanistan National Army (ANA) Trust Fund. December 2016. Available at: https://www. nato.int/nato_static_fl2014/assets/pdf/pdf_2016_12/20161206_1612-backgrounder-ana-en.pdf (accessed: 24.01.2019).

42. Afghanistan National Army (ANA) Trust Fund. December 2016. Available at: https://www.nato. int/nato_static_fl2014/assets/pdf/pdf_2018_12/20181203_1812-backgrounder-ana-trust-fund-en.pdf (accessed: 24.01.2019).

43. Defence Expenditure of NATO Countries (2011-2018). 10 July 2018. P. 8. Available at: https:// www.nato.int/nato_static_fl2014/assets/pdf/pdf_2018_07/20180709_180710-pr2018-91-en.pdf (accessed: 24.01.2019).

44. Poland among NATO States to Pledge More Troops to Afghanistan. Available at: http://www. thenews.pl/1/10/Artykul/334416,Poland-among-NATO-states-to-pledge-more-troops-to-Afghanistan (accessed: 24.01.2019).

45. Afghanistan: UK to Send 440 more Non-Combat Troops. Available at: https://www.bbc.com/ news/uk-44787636 (accessed: 15.09.2018). 
46. Johnson B. Beyond Brexit: A Global Britain. Foreign Secretary delivers first major policy speech at Chatham House. Available at: https://www.gov.uk/government/speeches/beyond-brexit-a-global-britain (accessed: 15.09.2018).

47. Britain to Almost Double Troops in Afghanistan after U.S. Request. Available at: https://www. reuters.com/article/us-nato-summit-britain-afghanistan/britain-to-almost-double-troops-in-afghanistanafter-u-s-request-idUSKBN1K02WM (accessed: 24.01.2019).

48. Beale J. Why Are UK and US Sending More Troops to Afghanistan? Available at: https://www.bbc. com/news/world-asia-44967531 (accessed: 24.01.2019).

49. Jenkins S. More British Troops Are Being Sent to Afghanistan - to Appease Trump. Available at: https://www.theguardian.com/commentisfree/2018/aug/13/british-troops-afghanistan-appease-trumpwar (accessed: 24.01.2019).

50. Kunz B. The Real Roots of Germany's Defense Spending Problem. Available at: https:// warontherocks.com/2018/07/the-real-roots-of-germanys-defense-spending-problem/ (accessed: 24.01.2019).

51. Federal Government Report to the Status of and Outlook for Germany's Afghanistan Engagement. Report to the German Bundestag. February 2018. Available at: https://www.auswaertigesamt.de/blob/1789270/e84f878742c319e5d93337c0b8b13c37/180315-perspektivbericht-data.pdf (accessed: 24.01.2019).

52. Koch M., Riedel D. Germany's 'Forever War' in Afghanistan. Available at: https://www.handelsblatt.com/today/politics/more-troops-germanys-forever-war-in-afghanistan/23581604.html?ticket=ST602466-bCAkXZg5xfUsbD3sXMmV-ap3 (accessed: 24.01.2019).

53. German Defense Minister Tells Troops in Afghanistan to Prepare for Long Haul. Available at: https://www.dw.com/en/german-defense-minister-tells-troops-in-afghanistan-to-prepare-for-longhaul/a-43123851 (accessed: 24.01.2019).

54. Braw E. The Future of Italy's International Military Footprint. Available at: https://rusi.org/commentary/future-italys-international-military-footprint (accessed: 24.01.2019).

55. Italy Not Against Upping NATO Contribution, but 'Assess First'. Available at: http://www.ansa. it/english/news/2017/05/25/italy-not-agst-upping-nato-contribution-but-assess-first_4d559c14-e0d54578-a3e1-2c4f49431aa1.html (accessed: 24.01.2019).

56. Italy should pull out of Afghanistan - M5S's Di Maio. Available at: http://www.ansa.it/english/ news/2018/02/06/italy-should-pull-out-of-afghanistan-m5ss-di-maio-2_7f38d55c-ea2f-4594-9223-cb48785cbf91.html (accessed: 24.01.2019).

57. Gonzalez M. España acepta la petición de tropas para Afganistán [Spain accepts the request of troops for Afghanistan]. El Pais, July 16, 2017. Available at: https://elpais.com/politica/2017/07/16/actualidad/1500220527_556489.html (accessed: 15.09.2018).

58. Greek Air Force Bolsters NATO Mission in Afghanistan. Available at: http://www.ekathimerini. com/230145/article/ekathimerini/news/greek-air-force-bolsters-nato-mission-in-afghanistan (accessed: 15.09.2018).

59. Mir bez Rossii? Evgenii Primakov: k chemu vedet politicheskaia blizorukost' [World without Russia: What Is the Result of Political Myopia?]. Available at: https://rg.ru/2009/01/21/primakov-kniga.html (accessed: 15.09.2018). (In Russian)

60. Marton P., Eichler J. Between Willing and Reluctant Entrapment: CEE Countries in NATO's nonEuropean Missions. Communist and Post-Communist Studies, 2013, 46, pp. 351-362.

61. Afghani Helicopter Pilots Train in Košice. Available at: https://spectator.sme.sk/c/20773928/afghani-helicopter-pilots-will-train-in-kosice.html (accessed: 17.09.2018).

62. "No plans to double our defense budget" Trudeau says. Available at: https://www.cbc.ca/news/politics/trudeau-latvia-visit-nato-1.4740098 (accessed: 17.09.2018).

63. France and NATO. France's Role in North Atlantic Treaty Organization. Available at: https://www. diplomatie.gouv.fr/en/french-foreign-policy/defence-security/france-and-nato/ (accessed: 17.09.2018).

64. France and Afghanistan. Available at: https://www.diplomatie.gouv.fr/en/country-files/afghanistan/france-and-afghanistan/ (accessed: 24.01.2019).

65. Hatto R. French Strategic Narratives, Public Opinion and the War in Afghanistan. Strategic Narratives, Public Opinion and War. Winning Domestic Support for the Afghan War. Eds B. de Graaf, G. Dimitriu, J. Ringsmose. New York, Routledge, 2015. 380 p. 
66. Afghanistan: le subit accès de réalisme de Trump [Afghanistan: Unexpected Approach of Trump’s Realism]. Le Monde, August 22, 2017. Available at: https://www.lemonde.fr/idees/article/2017/08/22/afghanistan-trump-cede-aux-generaux_5175107_3232.html (accessed: 24.01.2019).

67. NATO increasing troops in Afghanistan again, but Trudeau says Canadians won't be among them. Available at: https://www.cbc.ca/news/world/nato-troop-increase-afghanistan-1.4183549 (accessed: 24.01.2019).

68. Mr. Trump should negotiate a power-sharing agreement in Afghanistan. Available at: https:// www.washingtonpost.com/opinions/mr-trump-should-negotiate-a-power-sharing-agreement-in-afghanistan/2017/05/01/dd482b94-2c41-11e7-9081-f5405f56d3e4_story.html?utm_term=.3d8f9ff46ccc (accessed: 24.01.2019).

Received: September 19, 2018

Accepted: January 15, 2019

Author's information:

Boguslavskaya Yulia — PhD, Associate Professor; boguslawskaya@gmail.com 